\title{
Adsorption and Purification of Baicalin from Scutellaria baicalensis Georgi Extract by Ionic Liquids (ILs) Grafted Silica
}

\author{
Yunchang Fan ${ }^{1, *(\mathbb{D},}$, Di Wu ${ }^{1}$ and Sheli Zhang ${ }^{2}$ \\ 1 College of Chemistry and Chemical Engineering, Henan Polytechnic University, Jiaozuo 454003, China; \\ 211812010008@home.hpu.edu.cn \\ 2 College of Science and Technology, Jiaozuo Teachers College, Jiaozuo 454000, China; 1295006035@jzsz.edu.cn \\ * Correspondence: fanyunchang@hpu.edu.cn; Tel.: +86-391-398-6813
}

check for updates

Citation: Fan, Y.; Wu, D.; Zhang, S. Adsorption and Purification of Baicalin from Scutellaria baicalensis Georgi Extract by Ionic Liquids (ILs) Grafted Silica. Molecules 2021, 26, 2322. https://doi.org/10.3390/ molecules 26082322

Academic Editor: Santiago Aparicio

Received: 19 March 2021

Accepted: 14 April 2021

Published: 16 April 2021

Publisher's Note: MDPI stays neutral with regard to jurisdictional claims in published maps and institutional affiliations.

Copyright: (c) 2021 by the authors. Licensee MDPI, Basel, Switzerland. This article is an open access article distributed under the terms and conditions of the Creative Commons Attribution (CC BY) license (https:// creativecommons.org/licenses/by/ $4.0 /)$.

\begin{abstract}
Baicalin which has multiple biological activities is the main active component of the root of Scutellaria baicalensis Georgi (SBG). Although its isolation and purification by adsorption methods have aroused much interest of the scientific community, it suffered from the poor selectivity of the adsorbents. In this work, an environmentally benign method was developed to prepare ionic liquids (ILs) grafted silica by using IL 1-butyl-3-methylimidazolium bis(trifluoromethylsulfonyl)imide $\left(\left[\mathrm{C}_{4} \mathrm{mim}\right] \mathrm{NTf}_{2}\right)$ and ethanol as reaction media. The IL 1-propyl-3-methylimidazolium chloride $\left(\left[\mathrm{C}_{3} \mathrm{mim}\right] \mathrm{Cl}\right)$ grafted silica $\left(\left[\mathrm{C}_{3} \mathrm{mim}\right]^{+} \mathrm{Cl}^{-} @ \mathrm{SiO}_{2}\right)$ was used to adsorb and purify baicalin from the root extract of Scutellaria baicalensis Georgi (SBG). Experimental results indicated that the adsorption equilibrium can be quickly achieved (within $10 \mathrm{~min}$ ). The adsorption behavior of $\left[\mathrm{C}_{3} \mathrm{mim}\right]^{+} \mathrm{Cl}^{-} @ \mathrm{SiO}_{2}$ for baicalin was in good agreement with Langmuir and Freundlich models and the adsorption was a physisorption process as suggested by Dubinin-Radushkevich model. Compared with commercial resins, $\left[\mathrm{C}_{3} \mathrm{mim}\right]^{+} \mathrm{Cl}^{-} @ \mathrm{SiO}_{2}$ showed the strongest adsorption ability and highest selectivity. After desorption and crystallization, a purity of baicalin as high as $96.5 \%$ could be obtained. These results indicated that the ILs grafted silica materials were promising adsorbents for the adsorption and purification of baicalin and showed huge potential in the purification of other bioactive compounds from natural sources.
\end{abstract}

Keywords: ionic liquids (ILs); grafted silica; adsorption; baicalin; purification

\section{Introduction}

Scutellaria baicalensis Georgi (SBG) is one of the traditional medicine plants in Asia. Its roots are widely used as a remedy for the treatment of infection of the respiratory tract, inflammation, fever, and have anticancer, antimutagen, antiradical and lowering blood pressure effects [1-3]. Furthermore, the roots of SBG are also regarded as a popular functional food and usually used to stew soup with pork tripe or chicken in Asia [4]. Recent work reveals that baicalin is the main active ingredient of the roots of SBG and exhibits high antioxidant and hydroxyl radicals scavenging activity, which makes baicalin a potential cancer-chemopreventive agent against tumor promotion $[5,6]$. The extraction and purification of baicalin from SBG have aroused extensive concern among the scientific community. At present, many extraction methods including ultrasound-assisted extraction (UAE) [7,8], supercritical fluid extraction (SFE) [9], ultrahigh pressure extraction (UPE) [10], microwave-assisted extraction (MAE) [11], and heat reflux extraction (HRE) [7,12-15] were developed to isolate baicalin from SBG. After extraction, a purification procedure is needed to obtain high purity baicalin. In this context, adsorption method with polyamide [13] or macroporous resin [15] as adsorbents and counter-current chromatography (CCC) [8,14] have been used to purify baicalin from the extract of SBG. Although CCC was successively applied to purify baicalin, this technique involves the use of sophisticated instruments, 
which increases the operating cost [15]. Adsorption is a low-cost method with the advantage of ease of operation. Du et al. [15] used a non-polar macroporous resin (model HPD-100) to separate and purify baicalin from the extract of SBG. This resin exhibited good adsorption and desorption properties. After treatment with HPD-100 resin, the purity of baicalin was $58.3 \%$ with a recovery yield of $80.4 \%$. Chi et al. [13] used polyamide resin as an adsorbent to purify baicalin and studied the adsorption mechanism. The experimental results showed that the adsorption behavior of polyamide to baicalin agreed with the Freundlich equation and the baicalin with a purity of $33.86 \%$ (wt $\%$ ) was obtained after treatment with polyamide.

Based on the above discussion, there is an urgent necessity to develop a high-effective absorbent in order to obtain high-pure baicalin. As shown in Figure 1, baicalin is an organic acid, has a large $\pi$-conjugated structure and contains hydroxyl groups. These characteristics mean that baicalin has the tendency to form hydrogen bonds and to interact with other $\pi$-conjugated systems via $\pi-\pi$ stacking. Therefore, the adsorbent which has a $\pi$-conjugated structure and contains the groups easy to form hydrogen bonds may be a good choice to achieve high effective and selective adsorption for baicalin. Recently, ionic liquids (ILs) and their analogues, deep eutectic solvents (DESs) have been widely applied to extract bioactive compounds due to their excellent solubility for organic compounds [16-21]. Furthermore, imidazolium-based ILs have a $\pi$-conjugated structure and the $\mathrm{H}$ atom of $\mathrm{C} 2-\mathrm{H}$ on the imidazolium cation has the tendency to form hydrogen bonds with strongly electronegative atoms (e.g., O, N, and halide) (Figure 1) [22-25]. Therefore, the absorbents with their surfaces modified by ILs may provide high adsorption capacity and selectivity. At present, silica is usually used as carrier for immobilizing ILs due to its low-cost and nontoxic properties [26,27]. Two routes are usually adopted to covalently graft ILs to the surface of silica (Figure 2): (I) halide-containing group (e.g., 3-chloropropyl) was firstly introduced on the surface of silica via the reaction between silane coupling agents (e.g., (3-chloropropyl)trimethyoxysilane (CPTMOS)) and silica. Subsequently, the ILs were immobilized on the surface of silica through quaternization reaction [28-31]. (II) The ILs containing halide group were firstly synthesized via the reaction between alkylimidazole and silane coupling agents, following the grafting ILs to the silica surface via alcohol condensation [27,32,33]. As shown in Figure 2, current methods for the preparation of IL modified silica involve the use of dimethylformamide and toluene as reaction media. It is well known that dimethylformamide is carcinogenic [34] and clinical studies suggest that toluene is a neurotoxin which causes cerebral white matter damage [35]. It is of great importance to explore an environmental benign method which avoids the use of high toxic solvents. Toxic experiments indicate that the IL, 1butyl-3-methylimidazolium bis(trifluoromethylsulfonyl)imide $\left(\left[\mathrm{C}_{4} \mathrm{mim}\right] \mathrm{NTf}_{2}\right)$ is practically nontoxic towards marine and freshwater fish based on acute toxicity rating scale by fish and wildlife service (FWS) [36]. Additionally, the toxic assay by means of glucoseuptake inhibition experiments also shows that $\left[\mathrm{C}_{4} \mathrm{mim}\right] \mathrm{NTf}_{2}$ is not toxic at a concentration of $5 \%(v / v)$ [37]. These observations suggest that $\left[\mathrm{C}_{4} \mathrm{mim}\right] \mathrm{NTf}_{2}$ is a biocompatible solvent. Furthermore, $\left[\mathrm{C}_{4} \mathrm{mim}\right] \mathrm{NTf}_{2}$ has good solubility to silane reagents, such as tetraethyl orthosilicate (TEOS) and CPTMOS.
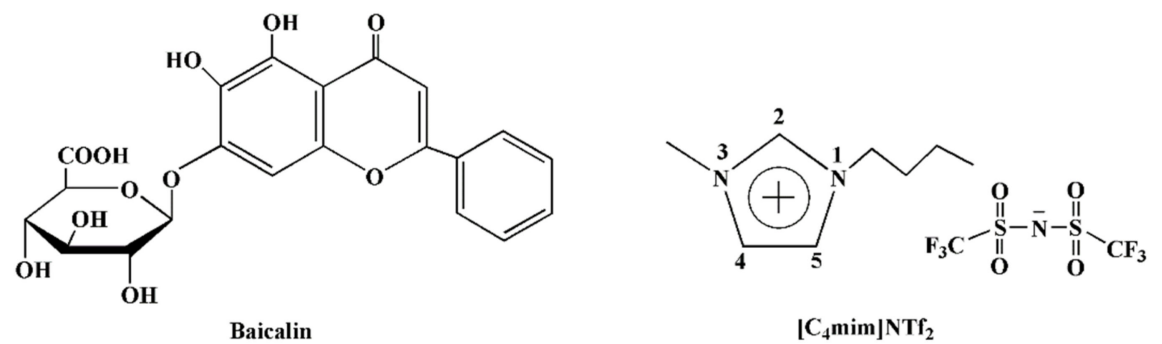

Figure 1. Chemical structures of baicalin and 1-butyl-3-methylimidazolium bis(trifluoromethylsulfonyl)imide $\left(\left[\mathrm{C}_{4} \operatorname{mim}\right] \mathrm{NTf}_{2}\right)$. 


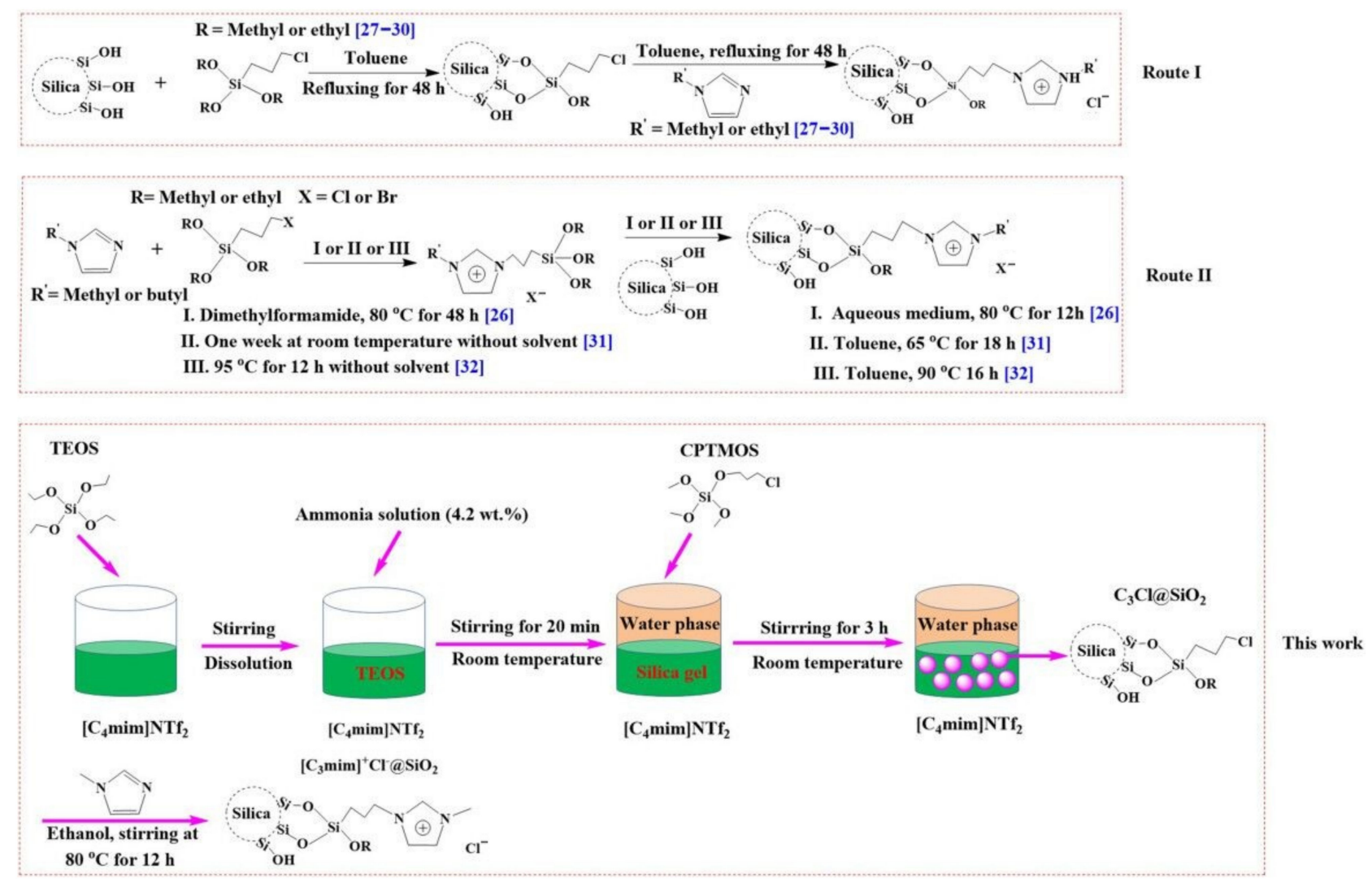

Figure 2. Schematic diagrams of the preparation of ILs grafted silica by reported routes and the proposed method.

Based on the above discussion, the present work suggested an environmentally benign method to prepare IL-supported silica (Figure 2): the silane reagents, TEOS and CPTMOS, were dissolved into $\left[\mathrm{C}_{4} \mathrm{mim}\right] \mathrm{NTf}_{2}$ and the hydrolysis occurred at the interface between IL and water phases (TEOS was allowed to hydrolyze for $20 \mathrm{~min}$ before the addition of CPTMOS due to their different hydrolytic rates). The resultant product was reacted with $\mathrm{N}$ methylimidazole in the medium of ethanol at $80^{\circ} \mathrm{C}$ for $8 \mathrm{~h}$ to produce the IL-modified silica. The adsorption and desorption behavior of this material for baicalin was systematically studied. Finally, it is believed that the IL-grafted silica will have great potential in practical purification of baicalin and the adsorption and purification of other natural bioactive compounds.

\section{Results and Discussion}

\subsection{Optimization of the Preparation Conditions of the ILs Grafted Silica}

In this work, the ILs grafted silica was prepared by two-step reactions: (I) the cohydrolysis and co-condensation of CPTMOS and TEOS in $\left[\mathrm{C}_{4}\right.$ mim]NTf $\mathrm{N}_{2}$ medium in the presence of ammonia solution $\left(\mathrm{NH}_{3}\right)$ to produce $\mathrm{C}_{3} \mathrm{Cl} @ \mathrm{SiO}_{2}$. (II) The quaternization reac-

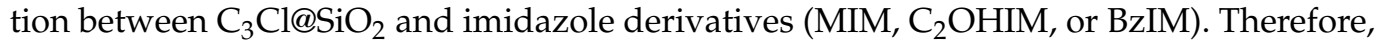
the reaction conditions such as the mole ratio of CPTMOS to TEOS, the dosages of $\mathrm{NH}_{3}$, the reaction time of quaternization and the dosage of $\left[\mathrm{C}_{4}\right.$ mim]NTf $\mathrm{N}_{2}$ were optimized using the preparation of $\left[\mathrm{C}_{3} \mathrm{mim}\right]^{+} \mathrm{Cl}^{-} @ \mathrm{SiO}_{2}$ as a representative. As shown in Figure 3a, with the mole ratio of CPTMOS to TEOS increasing from 0.25 to 1.0, the adsorption ability of the final product $\left[\mathrm{C}_{3} \mathrm{mim}\right]^{+} \mathrm{Cl}^{-} @ \mathrm{SiO}_{2}$ for baicalin increases. The reason lies in that CPTMOS is the active component, which can react with MIM to produce IL. However, further increase in the mole ratio of CPTMOS to TEOS leads to the decrease of the adsorption ability of $\left[\mathrm{C}_{3} \mathrm{mim}\right]^{+} \mathrm{Cl}^{-} @ \mathrm{SiO}_{2}$. Primary experiments suggest that without the addition of TEOS, i.e., only using CPTMOS as starting material, the final product $\left[\mathrm{C}_{3} \mathrm{mim}\right]^{+} \mathrm{Cl}^{-} @ \mathrm{SiO}_{2}$ is completely soluble in water. That is to say, high mole ratio of CPTMOS to TEOS results in the loss of IL from the surface of silica, subsequently decreasing the adsorption ability of 
$\left[\mathrm{C}_{3} \mathrm{mim}\right]^{+} \mathrm{Cl}^{-} @ \mathrm{SiO}_{2}$. based on this observation, 1.0 is selected as the optimal mole ratio of CPTMOS to TEOS for the preparation of $\left[\mathrm{C}_{3} \mathrm{mim}\right]^{+} \mathrm{Cl}^{-} @ \mathrm{SiO}_{2}$.

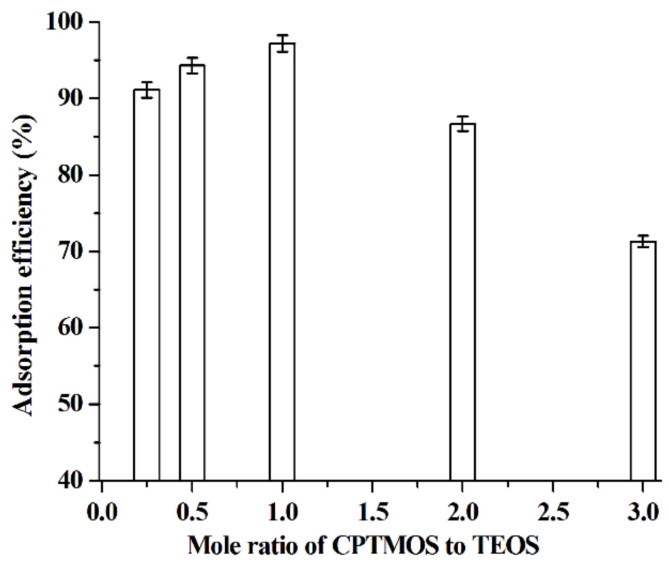

(a)

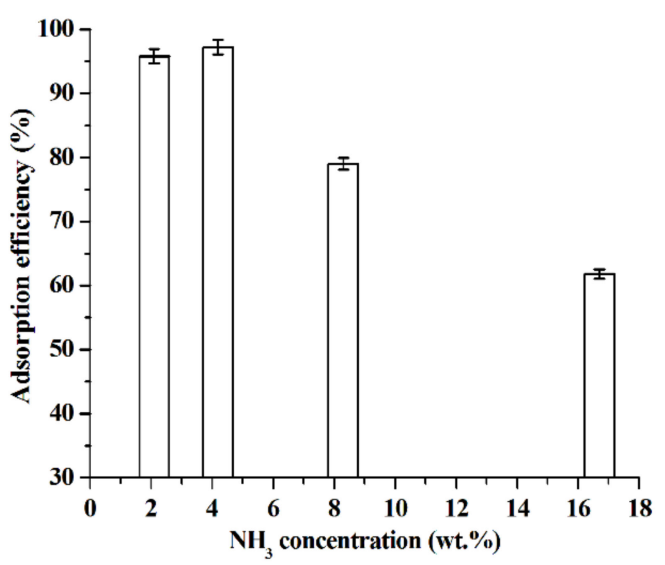

(b)

Figure 3. Effect of the mole ratio of CPTMOS to TEOS (a) (dosage of $\left[\mathrm{C}_{4}\right.$ mim] $\mathrm{NTf}_{2}, 1.0 \mathrm{~g} ; \mathrm{NH}_{3}$ concentration, $4.2 \mathrm{wt} \%$; quaternization reaction time, $12 \mathrm{~h}$; mole ratio of $\mathrm{MIM}$ to $\mathrm{C}_{3} \mathrm{Cl}_{\mathrm{S}} \mathrm{SiO}{ }_{2}$ of the quaternization reaction, 3.0; adsorption test: $\left[\mathrm{C}_{3} \mathrm{mim}\right]^{+} \mathrm{Cl}^{-} @ \mathrm{SiO}_{2}, 40 \mathrm{mg}$; baicalin aqueous solution, $5.0 \times 10^{-5} \mathrm{~mol} \cdot \mathrm{L}^{-1}, \mathrm{pH} 5.0,10 \mathrm{~mL}$; adsorption time, $1 \mathrm{~h}$; adsorption temperature, $25^{\circ} \mathrm{C}$ ) and $\mathrm{NH}_{3}$ concentration (b) (dosage of $\left[\mathrm{C}_{4} \mathrm{mim}\right] \mathrm{NTf}_{2}, 1.0 \mathrm{~g}$; mole ratio of CPTMOS to TEOS, 1.0; quaternization reaction time, $12 \mathrm{~h}$; mole ratio of $\mathrm{MIM}$ to $\mathrm{C}_{3} \mathrm{Cl}_{\mathrm{S}} \mathrm{SiO} \mathrm{O}_{2}$ of the quaternization reaction, 3.0; adsorption test: $\left[\mathrm{C}_{3} \mathrm{mim}\right]^{+} \mathrm{Cl}^{-} @ \mathrm{SiO}_{2}, 40 \mathrm{mg}$; baicalin aqueous solution, $5.0 \times 10^{-5} \mathrm{~mol} \cdot \mathrm{L}^{-1}, \mathrm{pH}$ 5.0, $10 \mathrm{~mL}$; adsorption time, $1 \mathrm{~h}$; adsorption temperature, $25^{\circ} \mathrm{C}$ ) on the adsorption efficiency of $\left[\mathrm{C}_{3} \mathrm{mim}\right]^{+} \mathrm{Cl}^{-} @ \mathrm{SiO}_{2}$. Experiments were conducted in triplicate.

Generally, $\mathrm{NH}_{3}$ acts as catalyst in the hydrolysis and condensation of TEOS and CPTMOS $[38,39]$. The effect of $\mathrm{NH}_{3}$ concentration on the adsorption ability of $\left[\mathrm{C}_{3} \mathrm{mim}\right]^{+} \mathrm{Cl}^{-} @ \mathrm{SiO}_{2}$ is shown in Figure $3 \mathrm{~b}$. As can be seen, $\left[\mathrm{C}_{3} \mathrm{mim}\right]^{+} \mathrm{Cl}^{-} @ \mathrm{SiO}_{2}$ has stronger adsorption ability for baicalin at lower $\mathrm{NH}_{3}$ concentration. The reason may lie in that lower $\mathrm{NH}_{3}$ concentration means lower reaction rates, which results in the better co-condensation of TEOS and CPTMOS. Furthermore, when $2.1 \mathrm{wt} \%$ of $\mathrm{NH}_{3}$ is adopted, the hydrolysis rate of TEOS is slow (the generation of silica gel requires about $40 \mathrm{~min}$ ). Therefore, $4.2 \mathrm{wt} \% \mathrm{of} \mathrm{NH}_{3}$ is selected for the following experiments.

To optimize the reaction conditions of quaternization, the mole ratio of MIM to $\mathrm{C}_{3} \mathrm{Cl} @ \mathrm{SiO}_{2}$ was firstly investigated and the results shown in Figure 4a indicate that excess amount of MIM is needed in order to convert more $\mathrm{C}_{3} \mathrm{Cl} @ \mathrm{SiO}_{2}$ to $\left[\mathrm{C}_{3} \mathrm{mim}\right]^{+} \mathrm{Cl}^{-} @ \mathrm{SiO}_{2}$. Based on this observation, 3.0 is selected as the optimal mole ratio of $\mathrm{MIM}$ to $\mathrm{C}_{3} \mathrm{Cl}_{\mathrm{SiO}}$. The effect of reaction time of quaternization shown in Figure $4 \mathrm{~b}$ suggests that $12 \mathrm{~h}$ is enough for the quaternization reaction between $\mathrm{MIM}$ and $\mathrm{C}_{3}{\mathrm{Cl} @ S i \mathrm{~S}_{2}}_{2}$. As shown in Figure 4c, with the use of $\left[\mathrm{C}_{4}\right.$ mim]NTf $\mathrm{Na}_{2}$ as reaction medium of the hydrolysis and condensation of TEOS and CPTMOS, $\left[\mathrm{C}_{3} \mathrm{mim}\right]^{+} \mathrm{Cl}^{-} @ \mathrm{SiO}_{2}$ shows stronger adsorption ability for baicalin. The reason may lie in that the hydrolysis and condensation of TEOS and CPTMOS occur at the interface of $\left[\mathrm{C}_{4} \mathrm{mim}\right] \mathrm{NTf}_{2}$ and water phases and thus the reaction rates are lower compared with the reaction system without the use of $\left[\mathrm{C}_{4} \mathrm{mim}_{\mathrm{NTf}}\right.$. Lower reaction rate means better co-condensation of TEOS and CPTMOS. Based on these results, $1.0 \mathrm{~g}$ of $\left[\mathrm{C}_{4} \mathrm{mim}_{\mathrm{NTf}}\right.$ is selected as the optimal IL dosage. 


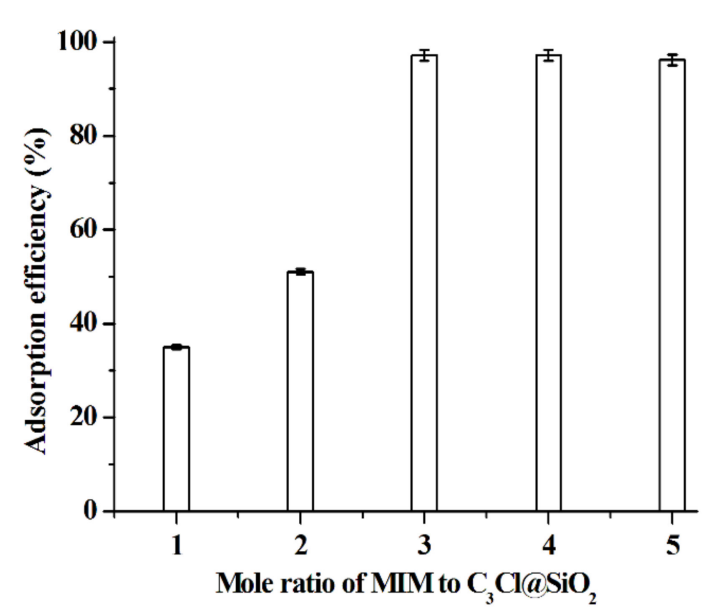

(a)

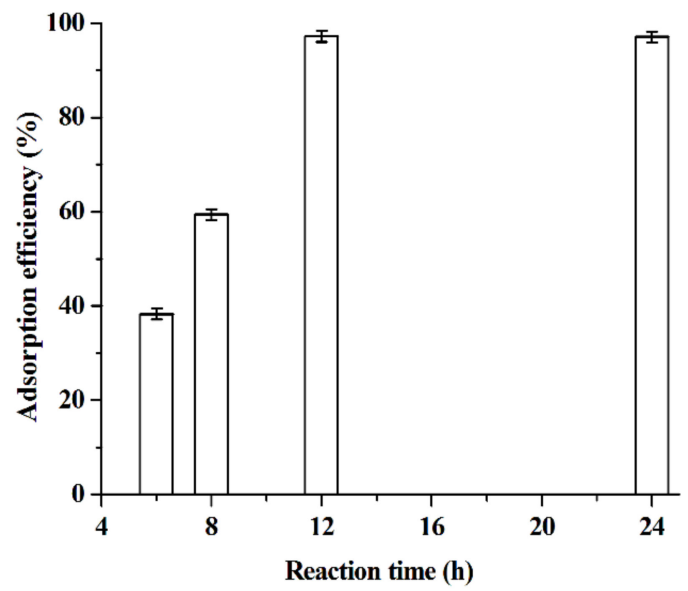

(b)

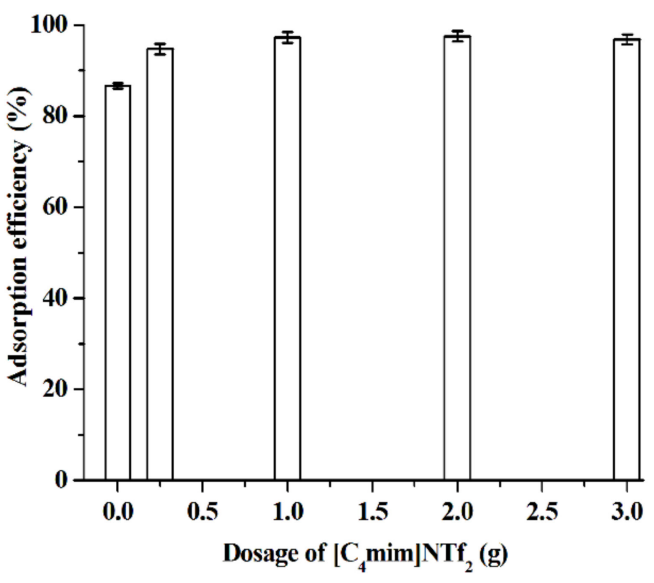

(c)

Figure 4. Effect of the mole ratio of $\mathrm{MIM}$ to $\mathrm{C}_{3} \mathrm{Cl} @ S i O_{2}(\mathrm{a})$ (dosage of $\left[\mathrm{C}_{4} \mathrm{mim}\right] \mathrm{NTf}_{2}, 1.0 \mathrm{~g}$; mole ratio of CPTMOS to TEOS, 1.0; $\mathrm{NH}_{3}$ concentration, $4.2 \mathrm{wt} \%$; quaternization reaction time, $12 \mathrm{~h}$; adsorption test: $\left[\mathrm{C}_{3} \mathrm{mim}^{+} \mathrm{Cl}^{-} @ \mathrm{SiO}_{2}, 40 \mathrm{mg}\right.$; baicalin aqueous solution, $5.0 \times 10^{-5} \mathrm{~mol} \cdot \mathrm{L}^{-1}$, $\mathrm{pH} 5.0,10 \mathrm{~mL}$; adsorption time, $1 \mathrm{~h}$; adsorption temperature, $25^{\circ} \mathrm{C}$ ), reaction time of quaternization (b) (dosage of $\left[\mathrm{C}_{4}\right.$ mim]NTf $\mathrm{N}_{2}, 1.0 \mathrm{~g}$; mole ratio of CPTMOS to TEOS, 1.0; $\mathrm{NH}_{3}$ concentration, $4.2 \mathrm{wt} \%$; mole ratio of $\mathrm{MIM}$ to $\mathrm{C}_{3} \mathrm{Cl} @ \mathrm{SiO}_{2}$ of the quaternization reaction, 3.0; adsorption test: $\left[\mathrm{C}_{3} \mathrm{mim}^{+} \mathrm{Cl}^{-} @ \mathrm{SiO}_{2}, 40 \mathrm{mg}\right.$; baicalin aqueous solution, $5.0 \times 10^{-5} \mathrm{~mol} \mathrm{~L}^{-1}$, pH 5.0, $10 \mathrm{~mL}$; adsorption time, $1 \mathrm{~h}$; adsorption temperature, $25^{\circ} \mathrm{C}$ ) and dosage of $\left[\mathrm{C}_{4}\right.$ mim]NTf 2 (c) (mole ratio of CPTMOS to TEOS, 1.0; $\mathrm{NH}_{3}$ concentration, $4.2 \mathrm{wt} \%$; mole ratio of $\mathrm{MIM}$ to $\mathrm{C}_{3} \mathrm{Cl}_{\mathrm{SSiO}}$ of the quaternization reaction, 3.0; quaternization reaction time, $12 \mathrm{~h}$; adsorption test: $\left[\mathrm{C}_{3} \mathrm{mim}^{+} \mathrm{Cl}^{-} @ \mathrm{SiO}_{2}, 40 \mathrm{mg}\right.$; baicalin aqueous solution, $5.0 \times 10^{-5} \mathrm{~mol} \cdot \mathrm{L}^{-1}$, $\mathrm{pH} 5.0,10 \mathrm{~mL}$; adsorption time, $1 \mathrm{~h}$; adsorption temperature, $25^{\circ} \mathrm{C}$ ) on the adsorption efficiency of $\left[\mathrm{C}_{3} \mathrm{mim}\right]^{+} \mathrm{Cl}^{-} @ \mathrm{SiO}_{2}$. Experiments were conducted in triplicate.

In summary, the optimal conditions for the preparation of the ILs grafted silica are as follows: mole ratio of CPTMOS to TEOS, $1.0 ; \mathrm{NH}_{3}$ concentration, $4.2 \mathrm{wt} \%$; mole ratio of $\mathrm{MIM}$ to $\mathrm{C}_{3} \mathrm{Cl} @ \mathrm{SiO}_{2}, 3.0$; reaction time, $12 \mathrm{~h}$; dosage of $\left[\mathrm{C}_{4} \mathrm{mim}\right] \mathrm{NTf}_{2}, 1.0 \mathrm{~g}$.

The $N$-(2-hydroxyethyl)imidazolium- and $N$-benzylimidazolium-based ILs grafted silica $\left[\mathrm{C}_{3} \mathrm{C}_{2} \mathrm{OHim}\right]^{+} \mathrm{Cl}^{-} @ \mathrm{SiO}_{2}$ and $\left[\mathrm{C}_{3} \mathrm{Bzim}\right]^{+} \mathrm{Cl}^{-} @ \mathrm{SiO}_{2}$ were also synthesized according to the above reaction conditions.

\subsection{Characterization of ILs Grafted Silica}

Elemental analysis and FT-IR spectra were used to confirm whether the ILs were grafted onto the surface of silica. Elemental analysis indicates that the $\mathrm{N}$ contents (wt $\%$ ) of $\mathrm{C}_{3} \mathrm{Cl} @ \mathrm{SiO}_{2},\left[\mathrm{C}_{3} \mathrm{mim}\right]^{+} \mathrm{Cl}^{-} @ \mathrm{SiO}_{2},\left[\mathrm{C}_{3} \mathrm{C}_{2} \mathrm{OHim}\right]^{+} \mathrm{Cl}^{-} @ \mathrm{SiO}_{2}$ and $\left[\mathrm{C}_{3} \mathrm{Bzim}\right]^{+} \mathrm{Cl}^{-} @ \mathrm{SiO}_{2}$ are $<0.01 \%, 1.52 \%, 1.26 \%$, and $1.26 \%$, respectively. The increase in the $\mathrm{N}$ content confirms the successful grafting ILs onto the silica surface. The FT-IR spectra of $\mathrm{C}_{3} \mathrm{Cl}_{\mathrm{SiO}}$, 
$\left[\mathrm{C}_{3} \mathrm{mim}\right]^{+} \mathrm{Cl}^{-} @ \mathrm{SiO}_{2},\left[\mathrm{C}_{3} \mathrm{C}_{2} \mathrm{OHim}\right]^{+} \mathrm{Cl}^{-} @ \mathrm{SiO}_{2}$ and $\left[\mathrm{C}_{3} \mathrm{Bzim}\right]^{+} \mathrm{Cl}^{-} @ \mathrm{SiO}_{2}$ are illustrated in

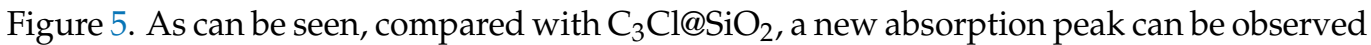
for the ILs grafted silica $\left(1564^{-1}\right.$ for $\left[\mathrm{C}_{3} \mathrm{C}_{2} \mathrm{OHim}\right]^{+} \mathrm{Cl}^{-} @ \mathrm{SiO}_{2}$ and $\left[\mathrm{C}_{3} \mathrm{Bzim}\right]^{+} \mathrm{Cl}^{-} @ \mathrm{SiO}_{2}$ and $1573 \mathrm{~cm}^{-1}$ for $\left.\left[\mathrm{C}_{3} \mathrm{mim}\right]^{+} \mathrm{Cl}^{-} @ \mathrm{SiO}_{2}\right)$, which corresponds to the $\mathrm{C}=\mathrm{N}$ stretching vibration of the imidazolium ring [40,41]. This observation also suggests that the ILs are successfully grafted onto the silica surface.

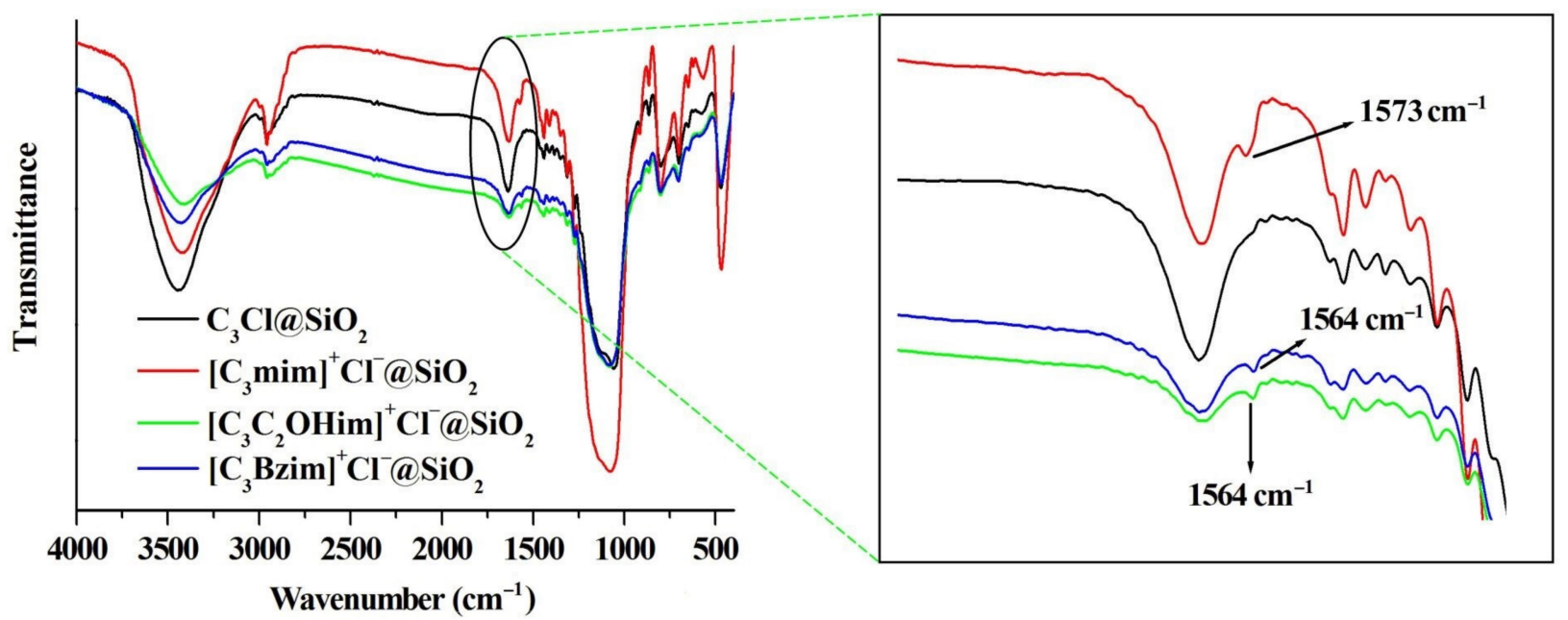

Figure 5. FT-IR spectra of $\mathrm{C}_{3} \mathrm{Cl} @ \mathrm{SiO}_{2},\left[\mathrm{C}_{3} \mathrm{mim}\right]^{+} \mathrm{Cl}^{-} @ \mathrm{SiO}_{2},\left[\mathrm{C}_{3} \mathrm{C}_{2} \mathrm{OHim}\right]^{+} \mathrm{Cl}^{-} @ \mathrm{SiO}_{2}$, and $\left[\mathrm{C}_{3} \mathrm{Bzim}^{+} \mathrm{Cl}^{-} @ \mathrm{SiO}_{2}\right.$.

The TEM and SEM images of $\left[\mathrm{C}_{3} \mathrm{mim}\right]^{+} \mathrm{Cl}^{-} @ \mathrm{SiO}_{2}$ are shown in Figure 6 and the TEM and SEM images of $\left[\mathrm{C}_{3} \mathrm{C}_{2} \mathrm{OHim}\right]^{+} \mathrm{Cl}^{-} @ \mathrm{SiO}_{2}$ and $\left[\mathrm{C}_{3} \mathrm{Bzim}\right]^{+} \mathrm{Cl}^{-} @ \mathrm{SiO}_{2}$ are demonstrated in Figures S1 and S2 in the Supplementary Materials. As can be seen from the TEM images, the ILs grafted silica products show a rough and wormhole-like structure. Their specific surface areas were determined and the experimental results indicate that the specific surface areas of $\left[\mathrm{C}_{3} \mathrm{mim}\right]^{+} \mathrm{Cl}^{-} @ \mathrm{SiO}_{2},\left[\mathrm{C}_{3} \mathrm{C}_{2} \mathrm{OHim}\right]^{+} \mathrm{Cl}^{-} @ \mathrm{SiO}_{2}$ and $\left[\mathrm{C}_{3} \mathrm{Bzim}\right]^{+} \mathrm{Cl}^{-} @ \mathrm{SiO}_{2}$ are $16.5 \mathrm{~m}^{2} \cdot \mathrm{g}^{-1}, 23.3 \mathrm{~m}^{2} \cdot \mathrm{g}^{-1}$ and $18.4 \mathrm{~m}^{2} \cdot \mathrm{g}^{-1}$, respectively. The SEM images of the ILs grated silica products (Figure 6 and Figures S1 and S2) show that all the products are amorphous and accumulations of small particles at micron scale. To further determine the particle size, all the products were tested by laser particle size analyzer and the results shown in Figure 7 and Figures S3 and S4 in the Supplementary Materials indicate that the average particle sizes of $\left[\mathrm{C}_{3} \mathrm{mim}\right]^{+} \mathrm{Cl}^{-} @ \mathrm{SiO}_{2},\left[\mathrm{C}_{3} \mathrm{C}_{2} \mathrm{OHim}\right]^{+} \mathrm{Cl}^{-} @ \mathrm{SiO}_{2}$, and $\left[\mathrm{C}_{3} \mathrm{Bzim}^{+} \mathrm{Cl}^{-} @ \mathrm{SiO}_{2}\right.$ are $5.9 \mu \mathrm{m}, 6.8 \mu \mathrm{m}$, and $10.7 \mu \mathrm{m}$, respectively.
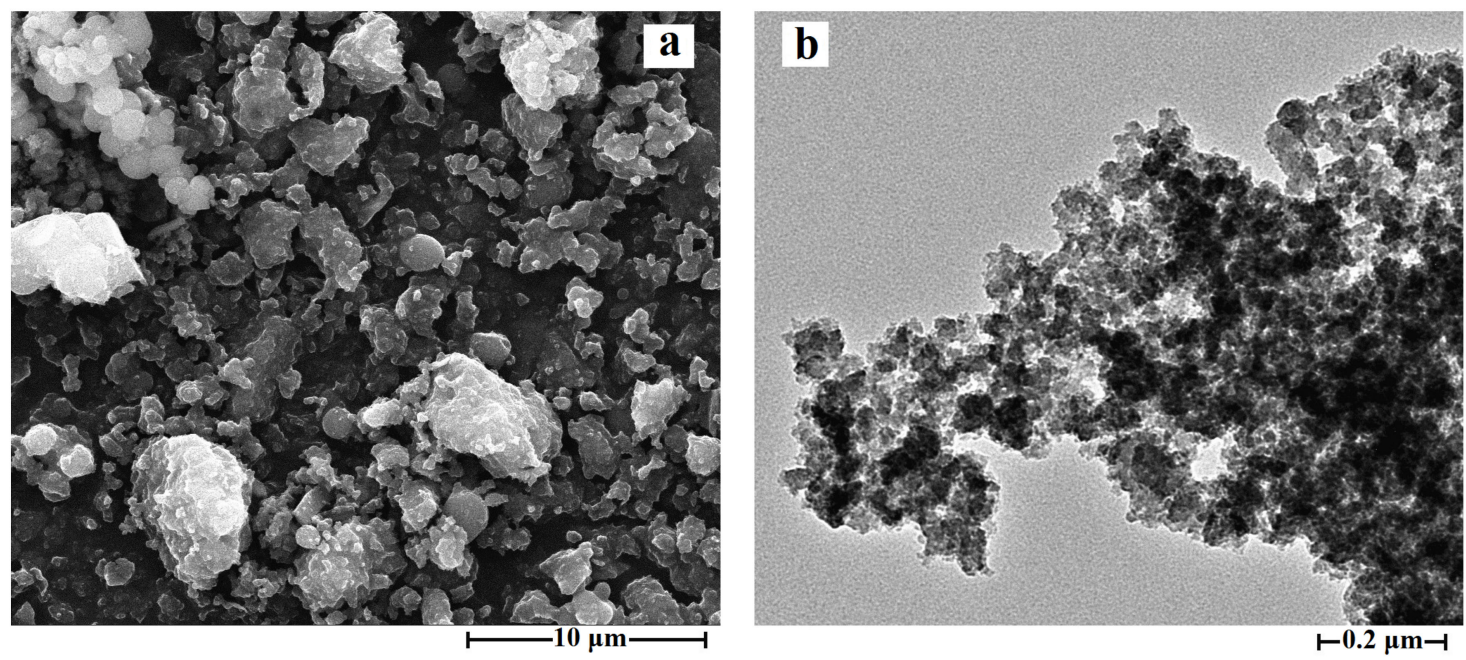

Figure 6. FE-SEM (a) and TEM (b) images of $\left[\mathrm{C}_{3} \mathrm{mim}\right]^{+} \mathrm{Cl}^{-} @ \mathrm{SiO}_{2}$. 


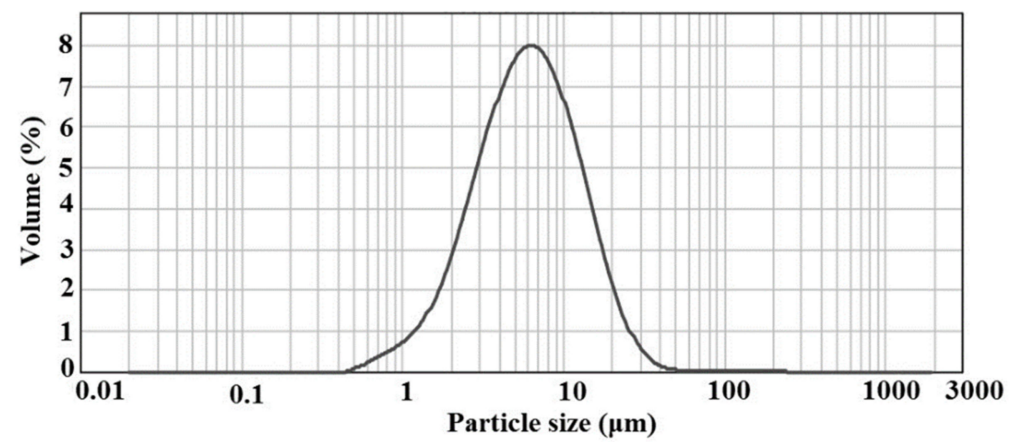

Figure 7. Particle size distribution of $\left[\mathrm{C}_{3} \mathrm{mim}\right]^{+} \mathrm{Cl}^{-} @ \mathrm{SiO}_{2}$.

\subsection{Adsorption Performance}

In this work, the three ILs grafted silica products were used to adsorb baicalin from aqueous phase and the results shown in Figure 8 suggest that at lower baicalin concentration $\left(5.0 \times 10^{-5} \mathrm{~mol} \cdot \mathrm{L}^{-1}\right)$, the three ILs grafted silica particles have similar adsorption ability (>97\%) and $\left[\mathrm{C}_{3} \mathrm{mim}\right]^{+} \mathrm{Cl}^{-} @ \mathrm{SiO}_{2}$ has the strongest absorption ability compared with $\left[\mathrm{C}_{3} \mathrm{C}_{2} \mathrm{OHim}\right]^{+} \mathrm{Cl}^{-} @ \mathrm{SiO}_{2}$ and $\left[\mathrm{C}_{3} \mathrm{Bzim}\right]^{+} \mathrm{Cl}^{-} @ \mathrm{SiO}_{2}$ at higher baicalin concentration $\left(9.0 \times 10^{-3} \mathrm{~mol} \cdot \mathrm{L}^{-1}\right)$. The reason may be that compared with $\left[\mathrm{C}_{3} \mathrm{mim}\right]^{+} \mathrm{Cl}^{-} @ \mathrm{SiO}_{2}$, $\left[\mathrm{C}_{3} \mathrm{C}_{2} \mathrm{OHim}\right]^{+} \mathrm{Cl}^{-} @ \mathrm{SiO}_{2}$, and $\left[\mathrm{C}_{3} \mathrm{Bzim}\right]^{+} \mathrm{Cl}^{-} @ \mathrm{SiO}_{2}$ bear larger size groups (hydroxyethyl for $\left[\mathrm{C}_{3} \mathrm{C}_{2} \mathrm{OHim}\right]^{+} \mathrm{Cl}^{-} @ \mathrm{SiO}_{2}$ and benzyl for $\left.\left[\mathrm{C}_{3} \mathrm{Bzim}\right]^{+} \mathrm{Cl}^{-} @ \mathrm{SiO}_{2}\right)$, which hinders the interaction between adsorbents and baicalin decreasing the adsorption ability of adsorbents. This phenomenon is the so-called steric hindrance effect. To investigate the adsorption ability and mechanism of the ILs grafted silica particles, the equilibrium data were firstly fitted by Langmuir (Equation (3)) and Freundlich (Equation (4)) models and the results are listed in Table 1 . As can be seen from Table 1 , the $1 / n$ values in the Freundlich equation are less than 1.0 (0.2959 to 0.3679$)$, suggesting that the adsorption of baicalin on the ILs grafted silica can occur easily $[15,42,43]$. Besides, both of the two models are suitable to describe the adsorption behavior of ILs grafted silica for baicalin, indicating the fact that both monolayer and heterogeneous surface conditions exist under the selected experimental conditions. This phenomenon was also observed when macroporous resin was used to adsorb and purify baicalin [15]. To further explore the types of adsorption, the equilibrium data were analyzed with the Dubinin-Radushkevich isotherm model. The results listed in Table 1 indicate that the $E$ values (average free energy) are in the range of $2.26 \mathrm{~kJ} \cdot \mathrm{mol}^{-1}$ to $2.44 \mathrm{~kJ} \cdot \mathrm{mol}^{-1}$, suggesting that the adsorption of baicalin onto the ILs grafted silica is a physisorption process due to $E<8.00 \mathrm{~kJ} \cdot \mathrm{mol}^{-1}[44,45]$.

Finally, considering the fact that $\left[\mathrm{C}_{3} \mathrm{mim}\right]^{+} \mathrm{Cl}^{-} @ \mathrm{SiO}_{2}$ has the strongest adsorption ability for baicalin, it is selected in the following experiments.

Table 1. Isotherm model parameters for the adsorption of baicalin onto ILs grafted silica $\left(\mathrm{pH} 5.0,25^{\circ} \mathrm{C}\right)$.

\begin{tabular}{|c|c|c|c|c|}
\hline $\begin{array}{l}\text { Isothermal Absorption } \\
\text { Models }\end{array}$ & Parameters & {$\left[\mathrm{C}_{3} \mathrm{mim}\right]^{+} \mathrm{Cl}^{-} @ \mathrm{SiO}_{2}$} & {$\left[\mathrm{C}_{3} \mathrm{C}_{2} \mathrm{OHim}^{+} \mathrm{Cl}^{-} @ \mathrm{SiO}_{2}\right.$} & {$\left[\mathrm{C}_{3} \text { Bzim }\right]^{+} \mathrm{Cl}^{-} @ \mathrm{SiO}_{2}$} \\
\hline \multirow[b]{2}{*}{ Langmuir model } & Fitted equation & $1 / Q_{e}=0.0039 / C_{e}+0.0028$ & $1 / Q_{\mathrm{e}}=0.0035 / C_{\mathrm{e}}+0.0034$ & $1 / Q_{e}=0.0037 / C_{e}+0.0038$ \\
\hline & $\begin{array}{l}\text { Correlation } \\
\text { coefficient }(r)\end{array}$ & 0.9991 & 0.9981 & 0.9920 \\
\hline \multirow[b]{3}{*}{ Freundlich model } & $Q_{\mathrm{m}}\left(\mathrm{mg} \cdot \mathrm{g}^{-1}\right)$ & $\begin{array}{c}357.1 \\
-0.1\end{array}$ & $\begin{array}{c}294.1 \\
-\end{array}$ & $\begin{aligned} 263.2 & \\
- & \end{aligned}$ \\
\hline & Fitted equation & $\ln Q_{e}=\underset{0.9929}{0.3679 \ln C_{e}}+5.0774$ & $\ln Q_{e}=\underset{0.3264 \ln C_{e}+5.0144}{0.9841}$ & $\ln Q_{e}=\underset{0.9990}{0.2959 \ln C_{e}}+4.9458$ \\
\hline & $1 / n$ & 0.3679 & 0.3264 & 0.2959 \\
\hline \multirow{4}{*}{$\begin{array}{l}\text { Dubinin-Radushkevich } \\
\text { model }\end{array}$} & $K_{\mathrm{F}}\left(\mathrm{mg} \cdot \mathrm{g}^{-1}\right)$ & 160.4 & 150.6 & 140.6 \\
\hline & Fitted equation & $\ln Q_{\mathrm{e}}=-0.0977 \varepsilon^{2}+5.5808$ & $\ln Q_{e}=-0.0837 \varepsilon^{2}+5.4671$ & $\ln Q_{e}=-0.0846 \varepsilon^{2}+5.3615$ \\
\hline & $E\left(\mathrm{~kJ} \cdot \mathrm{mol}^{-1}\right)$ & 2.26 & 2.44 & 2.43 \\
\hline & $Q_{m}\left(m g \cdot g^{-1}\right)$ & 265.3 & 236.8 & 213.0 \\
\hline
\end{tabular}




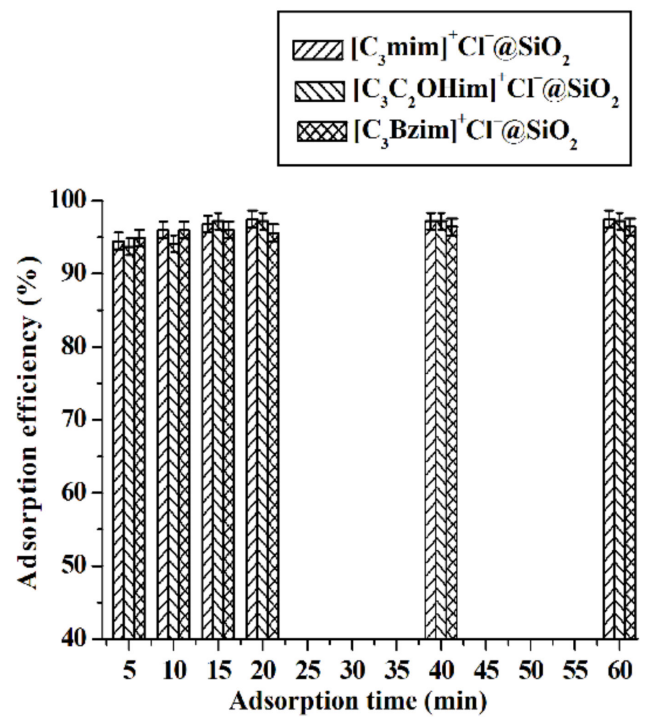

(a)

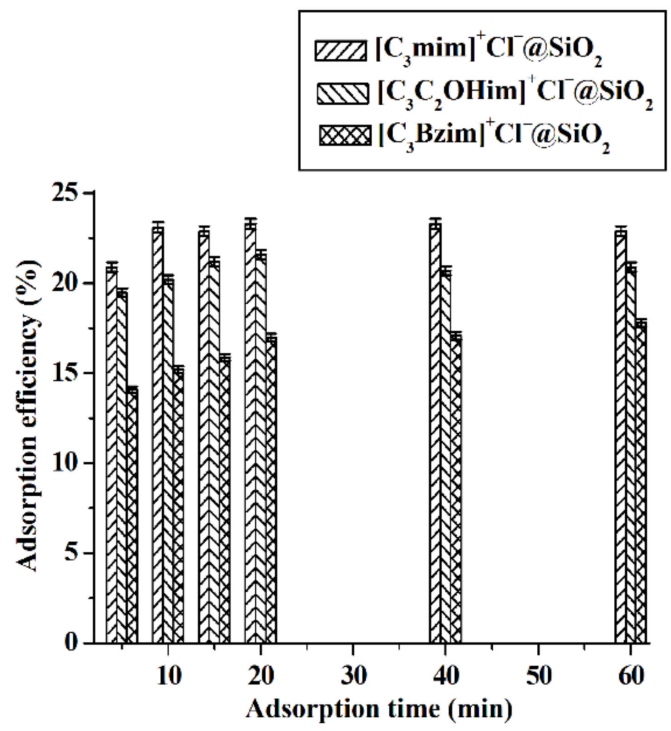

(b)

Figure 8. Adsorption efficiency of $\left[\mathrm{C}_{3} \mathrm{mim}\right]^{+} \mathrm{Cl}^{-} @ \mathrm{SiO}_{2},\left[\mathrm{C}_{3} \mathrm{C}_{2} \mathrm{OHim}\right]^{+} \mathrm{Cl}^{-} @ \mathrm{SiO}_{2}$ and $\left[\mathrm{C}_{3} \mathrm{Bzim}\right]^{+} \mathrm{Cl}^{-} @ \mathrm{SiO}_{2} \cdot(\mathrm{a}) \mathrm{C}_{\text {baicalin }}=5.0 \times 10^{-5} \mathrm{~mol} \cdot \mathrm{L}^{-1}$ and (b) $C_{\text {baicalin }}=9.0 \times 10^{-3} \mathrm{~mol} \cdot \mathrm{L}^{-1}$. Experimental conditions: adsorbent, $40 \mathrm{mg}$; volume of baicalin aqueous solution, $10 \mathrm{~mL}$; pH 5.0; adsorption temperature, $25^{\circ} \mathrm{C}$. Experiments were conducted in triplicate.

\subsection{Selection of the Adsorption Conditions of $\left[\mathrm{C}_{3} \mathrm{mim}\right]^{+} \mathrm{Cl}^{-} @ \mathrm{SiO}_{2}$}

In this work, the parameters affecting the adsorption ability of $\left[\mathrm{C}_{3} \mathrm{mim}\right]^{+} \mathrm{Cl}^{-} @ \mathrm{SiO}_{2}$ including adsorption time, $\mathrm{pH}$ and adsorption temperature were investigated. Data shown in Figure 8 indicate that the adsorption of baicalin can be completed in $10 \mathrm{~min}$. Therefore, $10 \mathrm{~min}$ is selected as the optimal adsorption time. The experimental results illustrated in Figure 9 suggest that the adsorption efficiency increases with the $\mathrm{pH}$ increasing from 2.0 to 5.0 and then keeps constant with further increasing the $\mathrm{pH}$ values. It is known that the dissociation constant $\left(\mathrm{p} K_{\mathrm{a}}\right)$ of baicalin is 2.9 [46]. When $\mathrm{pH}>\mathrm{p} K_{\mathrm{a}}$, baicalin exists in the form of anion, meaning that there exists strong electrostatic attraction between baicalin anion and the cation of $\left[\mathrm{C}_{3} \mathrm{mim}\right]^{+} \mathrm{Cl}^{-} @ \mathrm{SiO}_{2}$. That is to say, high adsorption efficiency would be achieved when $\mathrm{pH}>\mathrm{pK}_{\mathrm{a}} ; 5.0$ is thus regarded as the optimal $\mathrm{pH}$ value. As shown in Figure 10, the adsorption ability of $\left[\mathrm{C}_{3} \mathrm{mim}\right]^{+} \mathrm{Cl}^{-} @ \mathrm{SiO}_{2}$ decreases with the increase of temperature, indicating that the adsorption of baicalin is an exothermic adsorption process [47] and lower temperature is favorable for extraction. Thus, room temperature $25^{\circ} \mathrm{C}$ is selected for the adsorption of baicalin. 


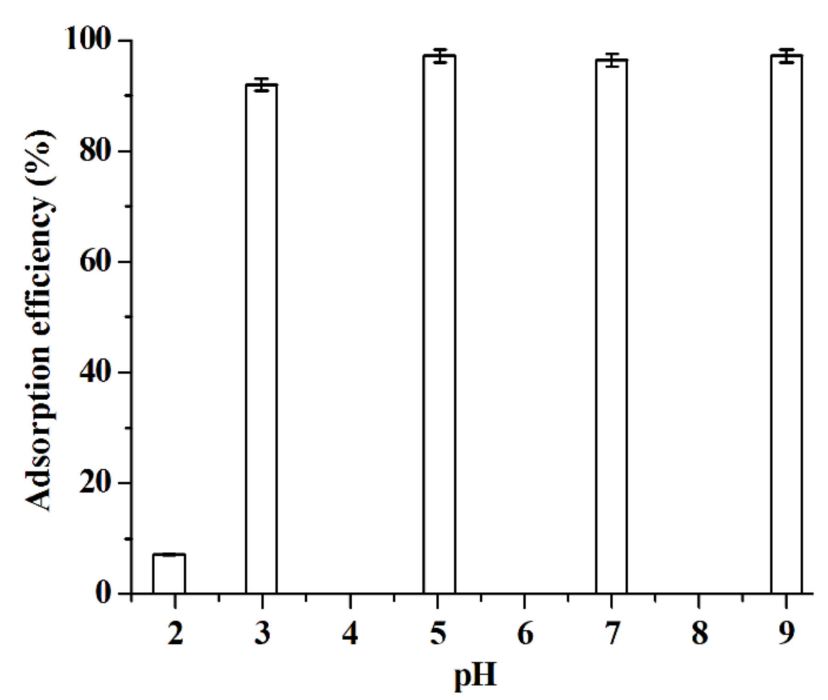

Figure 9. Effect of $\mathrm{pH}$ of water phase on the adsorption efficiency of $\left[\mathrm{C}_{3} \mathrm{mim}\right]^{+} \mathrm{Cl}^{-} @ \mathrm{SiO}_{2}$. Experimental conditions: $C_{\text {baicalin }}=5.0 \times 10^{-5} \mathrm{~mol} \cdot \mathrm{L}^{-1} ;\left[\mathrm{C}_{3} \mathrm{mim}\right]^{+} \mathrm{Cl}^{-} @ \mathrm{SiO}_{2}, 40 \mathrm{mg}$; volume of baicalin aqueous solutable $10 \mathrm{~mL}$; adsorption time, $10 \mathrm{~min}$; adsorption temperature, $25^{\circ} \mathrm{C}$. Experiments were conducted in triplicate.

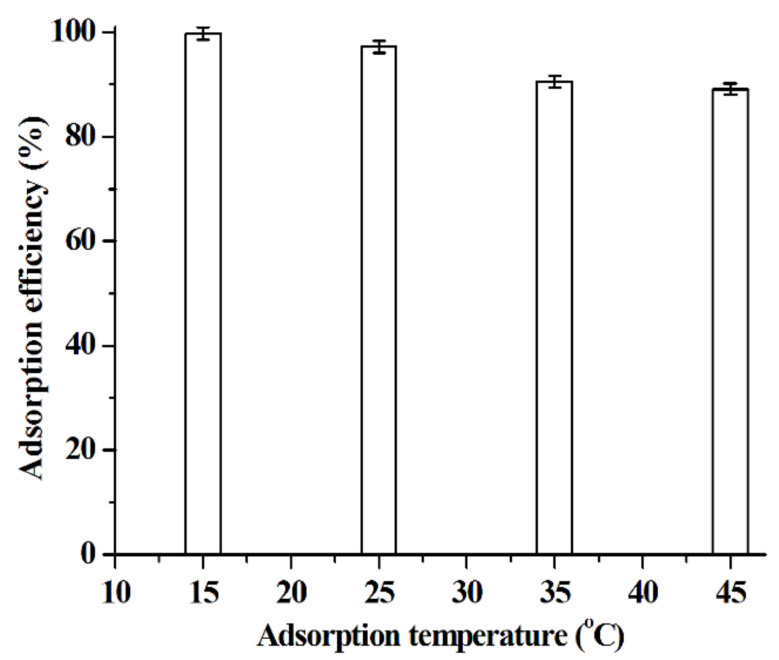

Figure 10. Effect of temperature on the adsorption efficiency of $\left[\mathrm{C}_{3} \mathrm{mim}\right]^{+} \mathrm{Cl}^{-} @ \mathrm{SiO}_{2}$. Experimental conditions: $\mathrm{C}_{\text {baicalin }}=5.0 \times 10^{-5} \mathrm{~mol} \cdot \mathrm{L}^{-1} ;\left[\mathrm{C}_{3} \mathrm{mim}\right]^{+} \mathrm{Cl}^{-} @ \mathrm{SiO}_{2}, 40 \mathrm{mg}$; volume of baicalin aqueous solution, $10 \mathrm{~mL}$; adsorption time, $10 \mathrm{~min}$; $\mathrm{pH}$ 5.0. Experiments were conducted in triplicate.

\subsection{Adsorption and Purification of Baicalin from the Root Extract of $S B G$}

Under the selected adsorption conditions, $\left[\mathrm{C}_{3} \mathrm{mim}\right]^{+} \mathrm{Cl}^{-} @ \mathrm{SiO}_{2}$ was used to absorb baicalin from the root extract of SBG. It is found that the baicalin concentration in the root extract of SBG is $1.9 \times 10^{-3} \mathrm{~mol} \cdot \mathrm{L}^{-1}$. Data shown in Figure 11 indicate that $0.2 \mathrm{~g}$ of $\left[\mathrm{C}_{3} \mathrm{mim}\right]^{+} \mathrm{Cl}^{-} @ \mathrm{SiO}_{2}$ can effectively adsorb baicalin from $10 \mathrm{~mL}$ of the extract $(96.5 \%)$ and this adsorption condition is thus selected. To achieve the desorption of baicalin, $\left[\mathrm{C}_{3} \mathrm{mim}\right]^{+} \mathrm{Cl}^{-} @ \mathrm{SiO}_{2}$ was washed with ethanol aqueous solution $(50 \%, v / v, \mathrm{pH} 3.0$ adjusted by $\mathrm{HCl}$ ) and the desorption efficiency is $97.4 \%$. After removing most of the solvent by vacuum distillation, the baicalin powder crystallizes and its purity is $96.5 \%$ (determined by the aforementioned HPLC method). Typical HPLC chromatograms of baicalin before and after purification with $\left[\mathrm{C}_{3} \mathrm{mim}\right]^{+} \mathrm{Cl}^{-} @ \mathrm{SiO}_{2}$ are shown in Figure 12. It can be seen that baicalin is successfully purified by $\left[\mathrm{C}_{3} \mathrm{mim}\right]^{+} \mathrm{Cl}^{-} @ \mathrm{SiO}_{2}$. 


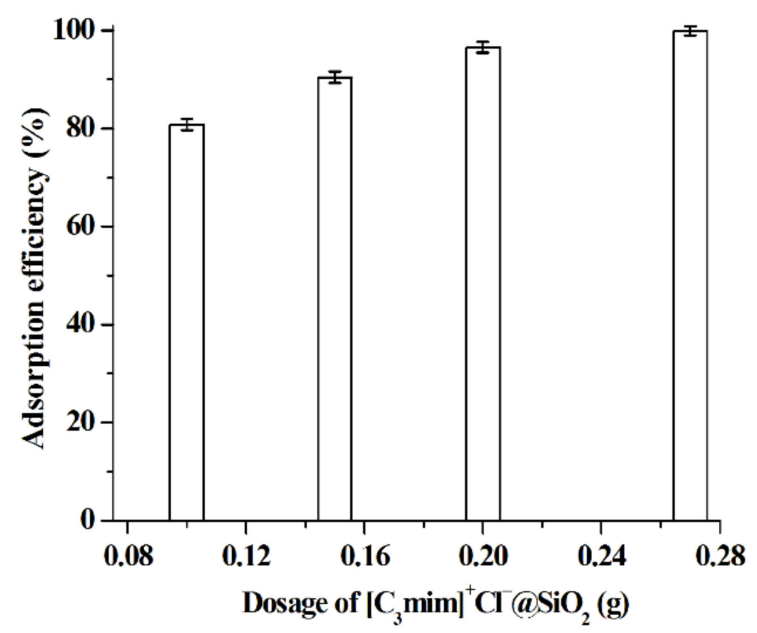

Figure 11. Effect of dosage of $\left[\mathrm{C}_{3} \mathrm{mim}\right]^{+} \mathrm{Cl}^{-} @ \mathrm{SiO}_{2}$ on the adsorption of baicalin from $10 \mathrm{~mL}$ of the root extract of SBG. Experimental conditions: $\mathrm{C}_{\text {baicalin }}=1.9 \times 10^{-3} \mathrm{~mol} \cdot \mathrm{L}^{-1}$; adsorption time, $10 \mathrm{~min}$; $\mathrm{pH}$ 5.0; adsorption temperature, $25^{\circ} \mathrm{C}$. Experiments were conducted in triplicate.

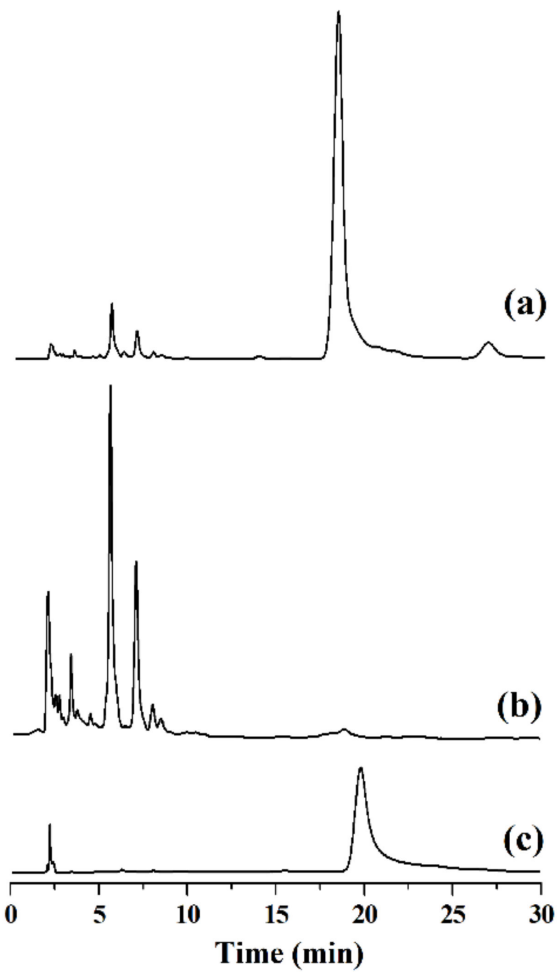

Figure 12. HPLC chromatograms of the root extract of SBG (a), the root extract of SBG after adsorption (b), and baicalin obtained from the desorption solution (c).

\subsection{Reusability of $\left[\mathrm{C}_{3} \mathrm{mim}\right]^{+} \mathrm{Cl}^{-} @ \mathrm{SiO}_{2}$ and Comparison with Literature Methods}

In this work, the reusability of $\left[\mathrm{C}_{3} \mathrm{mim}\right]^{+} \mathrm{Cl}^{-} @ \mathrm{SiO}_{2}$ is investigated and the results shown in Figure 13 indicate that $\left[\mathrm{C}_{3} \mathrm{mim}\right]^{+} \mathrm{Cl}^{-} @ \mathrm{SiO}_{2}$ can be reused at least seven times without loss of its adsorption efficiency. Furthermore, as mentioned above, the HPD-100 macroporous resin and polyamide resin were used to adsorb and purify baicalin. Therefore, a comparison on the adsorption performance between $\left[\mathrm{C}_{3} \mathrm{mim}\right]^{+} \mathrm{Cl}^{-} @ \mathrm{SiO}_{2}$ and the commercial adsorbents (HPD-100 macroporous resin and polyamide resin) was conducted and the results listed in Table 2 indicate that $\left[\mathrm{C}_{3} \mathrm{mim}^{+} \mathrm{Cl}^{-} @ \mathrm{SiO}_{2}\right.$ has the strongest adsorption ability and the fastest adsorption rate and provides the highest purity compared with HPD-100 macroporous resin and polyamide resin. 


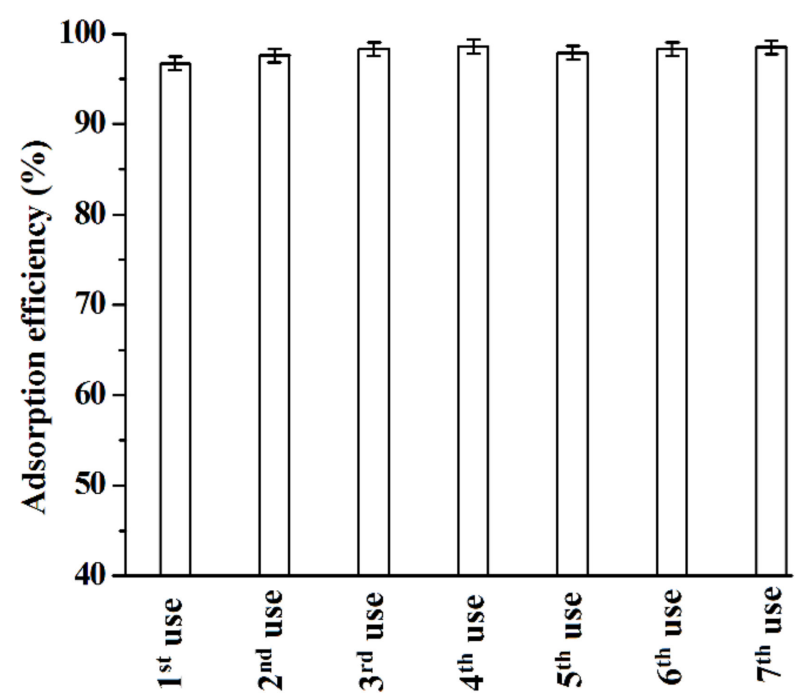

Figure 13. Reusability of $\left[\mathrm{C}_{3} \mathrm{mim}\right]^{+} \mathrm{Cl}^{-} @ \mathrm{SiO}_{2}$ for the adsorption of baicalin from the root extract of SBG. Experimental conditions: adsorption temperature, $25^{\circ} \mathrm{C}$; adsorption time, $10 \mathrm{~min} ; \mathrm{pH}, 5.0$; $\left[\mathrm{C}_{3} \mathrm{mim}\right]^{+} \mathrm{Cl}^{-} @ \mathrm{SiO}_{2}, 0.2 \mathrm{~g}$; volume of the root extract of $\mathrm{SBG}, 10 \mathrm{~mL}$. Experiments were conducted in triplicate.

Table 2. Comparison on the adsorption performance between $\left[\mathrm{C}_{3} \mathrm{mim}\right]^{+} \mathrm{Cl}^{-} @ \mathrm{SiO}_{2}$ and commercial adsorbents.

\begin{tabular}{|c|c|c|c|}
\hline Adsorbent & $Q_{\mathrm{e}}\left(\mathrm{mg} \cdot \mathrm{g}^{-1}\right)$ & $\begin{array}{l}\text { Adsorption Time } \\
\text { (min) }\end{array}$ & $\begin{array}{c}\text { Purity of Baicalin After } \\
\text { Desorption }\end{array}$ \\
\hline $\begin{array}{c}{\left[\mathrm{C}_{3} \mathrm{mim}\right]^{+} \mathrm{Cl}^{-} @ \mathrm{SiO}_{2} \text { (this }} \\
\text { work) }\end{array}$ & 357.1 & 10 & $96.5 \%$ \\
\hline $\begin{array}{l}\text { HPD-100 macroporous } \\
\text { resin [15] }\end{array}$ & 178.57 & 180 & $58.3 \%$ \\
\hline Polyamide resin [13] & 233.23 & 20 & $33.86 \%$ \\
\hline
\end{tabular}

\section{Materials and Methods}

\subsection{Materials}

Tetraethyl orthosilicate (TEOS, 98\%) and (3-chloropropyl)trimethyoxysilane (CPTMOS, 97\%) were obtained from Acros Organics (Bridgewater, NJ, USA). N-methylimidazole (MIM, 99\%) and baicalin (98\%) were supplied by Aladdin Bio-Chem Technology Co. (Shanghai, China). $\mathrm{N}$-(2-hydroxyethyl)imidazole $\left(\mathrm{C}_{2} \mathrm{OHIM}, 98 \%\right.$ ) and $\mathrm{N}$-benzylimidazole (BzIM, 98\%) were purchased from Changzhou Chongkai Chemical Co., Ltd. (Changzhou, China). Roots of SBG were purchased from Hebeikangan Bio-Technology Co., Ltd. (Anguo, China) and ground into powder with a particle size of around 100 mesh. Macroporous resin (model HPD-100, 60-16 mesh) was obtained from Donghong Chemical Co., Ltd. (Kunshan, China). 1-Butyl-3-methylimidazolium bis(trifluoromethylsulfonyl)imide $\left(\left[\mathrm{C}_{4} \mathrm{mim} \mathrm{NTf}_{2}\right)\right.$ was purchased from Lanzhou Institute of Chemical Physics (Lanzhou, China).

\subsection{Methods}

\subsubsection{Synthesis of ILs Grafted Silica}

Typically, $1.0 \mathrm{~g}$ of TEOS was dissolved into $1.0 \mathrm{~g}$ of $\left[\mathrm{C}_{4} \mathrm{mim}_{\mathrm{NTf}}\right.$, followed by the addition of $1.5 \mathrm{~mL}$ of ammonia solution (4.2 $\mathrm{wt} \%$ ). This mixture was stirred at room temperature for $20 \mathrm{~min}$ to produce silica gel and then $0.95 \mathrm{~g}$ of CPTMOS was added. The resultant mixture was subject to another $3 \mathrm{~h}$ of stirring. After dissolving with ethanol and filtering, CPTMOS-modified silica (denoted as $\mathrm{C}_{3} \mathrm{Cl}_{\mathrm{SSiO}}$ ) was obtained. To graft $\mathrm{N}$-methylimidazolium-based IL on the surface of silica, CPTMOS-modified silica $(0.2 \mathrm{~g})$ and $\mathrm{N}$-methylimidazole $(0.33 \mathrm{~g})$ were dispersed into $15 \mathrm{~mL}$ of ethanol. This mixture was stirred at $80^{\circ} \mathrm{C}$ for $12 \mathrm{~h}$ to generate IL-modified silica (denoted as $\left[\mathrm{C}_{3} \mathrm{mim}\right]^{+} \mathrm{Cl}^{-} @ \mathrm{SiO}_{2}$ ). 
The synthesized $\left[\mathrm{C}_{3} \mathrm{mim}\right]^{+} \mathrm{Cl}^{-} @ \mathrm{SiO}_{2}$ was washed with ethanol and then dried at $60{ }^{\circ} \mathrm{C}$ for $3 \mathrm{~h}$. The grafting of $N$-(2-hydroxyethyl)imidazolium- and $N$-benzylimidazolium-based ILs on the surface of silica followed a similar way and the resultant products were denoted as $\left[\mathrm{C}_{3} \mathrm{C}_{2} \mathrm{OHim}\right]^{+} \mathrm{Cl}^{-} @ \mathrm{SiO}_{2}$ and $\left[\mathrm{C}_{3} \mathrm{Bzim}^{+} \mathrm{Cl}^{-} @ \mathrm{SiO}_{2}\right.$, respectively.

\subsubsection{Characterization of ILs Grafted Silica}

All the ILs grafted silica products were characterized by an elemental analyzer (model FLASH 2000, Thermo Fisher Scientific, Belmont, MA, USA), a field-emission scanning electron microscope (FE-SEM, Quanta 250 FEG, Thermo Fisher Scientific, Hillsboro, OR, USA), a transmission electron microscope (TEM, model Tecnai G2 20, FEI, Hillsboro, OR, USA), a surface area and porosity analyzer (model ASAP 2460, Micromeritics Instrument Corp., Norcross, GA, USA), a Fourier transform infrared (FT-IR) spectrophotometer (model V70, Bruker Optic GmbH, Ettlingen, Germany) and a laser particle sizer (model Mastersizer 2000, Malvern Instruments Ltd., Malvern, UK). The FT-IR spectra of the ILs grafted silica in transmission mode were measured by the $\mathrm{KBr}$ pressed disc method. The particle size distribution of the ILs grafted silica was determined by the laser diffraction method using Mastersizer 2000 and water was used as dispersive solvent.

\subsubsection{Preparation of the Root Extract of SBG}

The preparation of the root extract of SBG was conducted by referring to the reported work with minor modification [12,15]: $1.0 \mathrm{~g}$ of SBG powder and $100 \mathrm{~mL}$ of water were mixed under stirring at $100{ }^{\circ} \mathrm{C}$ for $30 \mathrm{~min}$. After filtering, the water phase was collected and stored in refrigerator before use.

\subsubsection{Determination of Baicalin}

The baicalin concentration in water phase was determined by high performance liquid chromatography (HPLC) using an Agilent 1200 HPLC system (Agilent Technologies, Santa Clara, CA, USA). The chromatographic conditions are as follows: mobile phase, the mixture of acetonitrile $(17 \%, v / v)$ and $0.1 \%(v / v)$ of acetic acid aqueous solution $(83 \%$, $v / v$ ); flow-rate, $0.8 \mathrm{~mL} \cdot \mathrm{min}^{-1}$; separation column, ZORBAX Eclipse XDB-C18 column $\left(4.6 \times 150 \mathrm{~mm}, 5 \mu \mathrm{m}\right.$, Agilent); column temperature, $30{ }^{\circ} \mathrm{C}$; detection wavelength, $275 \mathrm{~nm}$; injection volume, $5 \mu \mathrm{L}$.

\subsubsection{Adsorption and Desorption of Baicalin}

For a typical adsorption procedure, $40 \mathrm{mg}$ of $\left[\mathrm{C}_{3} \mathrm{mim}\right]^{+} \mathrm{Cl}^{-} @ \mathrm{SiO}_{2}$ was mixed with $10 \mathrm{~mL}$ of baicalin aqueous solution $\left(5.0 \times 10^{-5} \mathrm{~mol} \cdot \mathrm{L}^{-1}, \mathrm{pH} 5.0\right)$ under stirring at room temperature for $10 \mathrm{~min}$. After filtering, $\left[\mathrm{C}_{3} \mathrm{mim}\right]^{+} \mathrm{Cl}^{-} @ \mathrm{SiO}_{2}$ powder was washed with ethanol aqueous solution $(50 \%, v / v, \mathrm{pH} 3.0$ adjusted by $\mathrm{HCl})$ to recover baicalin and to regenerate the absorbent.

The adsorption capacity $\left(Q_{\mathrm{e}}\right)$ and adsorption efficiency $(E)$ are expressed by the following equations (Equations (1) and (2)):

$$
\begin{gathered}
Q_{e}=\frac{V\left(C_{0}-C_{\mathrm{e}}\right)}{m} \\
E=\frac{\left(C_{0}-C_{\mathrm{e}}\right)}{C_{0}} \times 100 \%
\end{gathered}
$$

where $Q_{\mathrm{e}}\left(\mathrm{mg} \cdot \mathrm{g}^{-1} \mathrm{dry}\right.$ absorbent), $V, C_{0}, C_{\mathrm{e}}, m, E$, are the adsorption capacity of absorbent to baicalin at equilibrium, volume of baicalin solution, initial baicalin concentration, equilibrium concentration of baicalin after adsorption, dry weight of adsorbent and adsorption efficiency, respectively.

The adsorption behavior of adsorbent was analyzed using Langmuir, Freundlich, and Dubinin-Radushkevich equations [15,42-45], respectively: 
Langmuir equation (Equation (3)):

$$
\frac{1}{Q_{e}}=\frac{1}{Q_{m} K_{L}} \frac{1}{C_{e}}+\frac{1}{Q_{m}}
$$

Freundlich equation (Equation (4)):

$$
\ln Q_{\mathrm{e}}=\ln K_{\mathrm{F}}+\frac{1}{n} \ln C_{\mathrm{e}}
$$

where $Q_{\mathrm{e}}, Q_{\mathrm{m}}, K_{\mathrm{L}}, C_{\mathrm{e}}, K_{\mathrm{F}}$, and $1 / n$ are the adsorption capacity (mg.g ${ }^{-1}$ dry absorbent), the maximum adsorption capacity $\left(\mathrm{mg} \cdot \mathrm{g}^{-1}\right.$ dry absorbent), the Langmuir constant, the equilibrium concentration of baicalin after adsorption, the Freundlich constant and an empirical constant related to the adsorption intensity, respectively.

The Dubinin-Radushkevich equations are expressed as (Equations (5)-(7)):

$$
\begin{gathered}
\ln Q_{\mathrm{e}}=\ln Q \mathrm{~m}-K \varepsilon^{2} \\
\varepsilon=\mathrm{R} T \ln \left(1+1 / C_{\mathrm{e}}\right) \\
E=1 / \sqrt{2 K}
\end{gathered}
$$

where $K\left(\mathrm{~mol}^{2} \cdot \mathrm{kJ}^{-2}\right)$ is the activity coefficient related to mean free energy of adsorption; $\varepsilon$ $\left(\mathrm{kJ} \cdot \mathrm{mol}^{-1}\right)$ is the Polanyi potential; $\mathrm{R}\left(8.314 \mathrm{~J} \cdot \mathrm{mol}^{-1} \cdot \mathrm{K}^{-1}\right)$ is the gas constant and $T(\mathrm{~K})$ is Kelvin temperature; $E\left(\mathrm{~kJ} \cdot \mathrm{mol}^{-1}\right)$ is the average free energy of adsorption.

\section{Conclusions}

In this work, a two-step method was developed to prepare ILs grafted silica: (I) the co-hydrolysis and co-condensation of CPTMOS and TEOS in $\left[\mathrm{C}_{4}\right.$ mim] $\mathrm{NTf}_{2}$ medium to produce $\mathrm{C}_{3} \mathrm{Cl} @ \mathrm{SiO}_{2}$; and (II) the quaternization reaction between $\mathrm{C}_{3} \mathrm{Cl} @ \mathrm{SiO}_{2}$ and imidazole derivatives to generate ILs grafted silica. Compared with the reported methods, the developed technique to prepare ILs grafted silica was easier to operate and more environmentally benign because the use of toxic solvents, such as dimethylformamide and toluene was avoided. Compared with the commercial HPD-100 macroporous resin and polyamide resin, the synthesized IL grafted silica, $\left[\mathrm{C}_{3} \mathrm{mim}\right]^{+} \mathrm{Cl}^{-} @ \mathrm{SiO}_{2}$ exhibited strongest adsorption ability, fastest adsorption rate and could provide highest purity of baicalin $(96.5 \%)$. These results suggested that ILs were promising media for the preparation of silica-based materials and had huge potential in the synthesis of other functional materials. Finally, ILs grafted silica exhibited great potential in the separation and purification of baicalin from SBG and may be applied for the adsorption and purification of other bioactive compounds with similar chemical structures.

Supplementary Materials: The following are available online. Figure S1: The FE-SEM (A) and TEM (B) images of $\left[\mathrm{C}_{3} \mathrm{C}_{2} \mathrm{OHim}\right]^{+} \mathrm{Cl}^{-} @ \mathrm{SiO}_{2}$; Figure S2. The FE-SEM (A) and TEM (B) images of $\left[\mathrm{C}_{3} \mathrm{Bzim}\right]^{+} \mathrm{Cl}^{-} @ \mathrm{SiO}_{2}$; Figure S3. Particle size distribution of $\left[\mathrm{C}_{3} \mathrm{C}_{2} \mathrm{OHim}\right]^{+} \mathrm{Cl}^{-} @ \mathrm{SiO}_{2}$; Figure S4. Particle size distribution of $[\mathrm{C} 3 \mathrm{Bzim}]^{+} \mathrm{Cl}^{-} @ \mathrm{SiO}_{2}$.

Author Contributions: Conceptualization, Y.F.; Methodology, D.W.; Validation, D.W. and S.Z.; Formal analysis, Y.F.; Investigation, D.W.; Resources, Y.F.; Data curation, D.W.; Writing-original draft preparation, Y.F.; Writing-review and editing, Y.F.; Visualization, Y.F.; Supervision, Y.F.; Project administration, Y.F.; Funding acquisition, Y.F. All authors have read and agreed to the published version of the manuscript.

Funding: This research was funded by the Foundation of Henan province, grant number 182102310728 and the Foundation of Henan Polytechnic University, grant number NSFRF200313.

Data Availability Statement: Data is contained within the article.

Conflicts of Interest: The authors declare no conflict of interest. 
Sample Availability: Samples of the compounds baicalin and ILs grafted silica are available from the authors.

\section{References}

1. Wozniak, D.; Lamer-Zarawska, E.; Matkowski, A. Antimutagenic and antiradical properties of flavones from the roots ofScutellaria baicalensis Georgi. Food/Nahrung 2004, 48, 9-12. [CrossRef]

2. Huang, W.-H.; Lee, A.-R.; Yang, C.-H. Antioxidative and Anti-Inflammatory Activities of Polyhydroxyflavonoids of Scutellaria baicalensisGEORGI. Biosci. Biotechnol. Biochem. 2006, 70, 2371-2380. [CrossRef]

3. Chan, S.W.; Li, S.; Kwok, C.Y.; Benzie, I.F.F.; Szeto, Y.T.; Guo, D.J.; He, X.P.; Yu, P.H.F. Antioxidant activity of Chinese me-dicinal herbs. Pharm. Biol. 2008, 46, 587-595. [CrossRef]

4. Chan, E.; Wong, C.Y.-K.; Wan, C.-W.; Kwok, C.-Y.; Wu, J.-H.; Ng, K.-M.; So, C.-H.; Au, A.L.-S.; Poon, C.C.-W.; Seto, S.-W.; et al. Evaluation of Anti-Oxidant Capacity of Root of Scutellaria baicalensis Georgi, in Comparison with Roots of Polygonum multiflorum Thunb and Panax ginseng CA Meyer. Am. J. Chin. Med. 2010, 38, 815-827. [CrossRef] [PubMed]

5. Lee, M.J.; Wang, C.J.; Tsai, Y.Y.; Hwang, J.M.; Lin, W.L.; Tseng, T.H.; Chu, C.Y. Inhibitory effect of 12-O-tetradecanoylphorbol13-acetate-caused tumor promotion in benzo[a]pyrene-initiatedCD-1 mouse skin by baicalein. Nutr. Cancer 1999, 34, $185-191$. [CrossRef] [PubMed]

6. Shi, H.; Zhao, B.; Xin, W. Scavenging effects of baicalin on free radicals and its protection on erythrocyte membrane from free radical injury. Biochem. Mol. Boil. Int. 1995, 35, 981-994.

7. Yang, Y.-C.; Wei, M.-C.; Huang, T.-C.; Lee, S.-Z.; Lin, S.-S. Comparison of modified ultrasound-assisted and traditional extraction methods for the extraction of baicalin and baicalein from Radix Scutellariae. Ind. Crop. Prod. 2013, 45, 182-190. [CrossRef]

8. Wang, C.; Sun, W.; Wang, X.; Jin, Y.; Zhao, S.; Luo, M.; Tong, S. Large-scale separation of baicalin and wogonoside from Scutellaria baicalensis Georgi by the combination of $\mathrm{pH}$-zone-refining and conventional counter-current chromatography. J. Chromatogr. A 2019, 1601, 266-273. [CrossRef] [PubMed]

9. Chang, Y.; Liu, B.; Shen, B. Orthogonal array design for the optimization of supercritical fluid extraction of baicalinfrom roots of Scutellaria baicalensis Georgi. J. Sep. Sci. 2007, 30, 1568-1574. [CrossRef]

10. Wang, H.; Ma, X.; Cheng, Q.; Wang, L.; Zhang, L. Deep Eutectic Solvent-Based Ultrahigh Pressure Extraction of Baicalin from Scutellaria baicalensis Georgi. Molecules 2018, 23, 3233. [CrossRef]

11. Wang, H.; Ma, X.; Cheng, Q.; Xi, X.; Zhang, L. Deep Eutectic Solvent-Based Microwave-Assisted Extraction of Baicalin from Scutellaria baicalensis Georgi. J. Chem. 2018, 2018. [CrossRef]

12. Bi, P.-Y.; Chang, L.; Mu, Y.-L.; Liu, J.-Y.; Wu, Y.; Geng, X.; Wei, Y. Separation and concentration of baicalin from Scutellaria Baicalensis Georgi extract by aqueous two-phase flotation. Sep. Purif. Technol. 2013, 116, 454-457. [CrossRef]

13. Chi, R.-A.; Zhou, F.; Huang, K.; Zhang, Y.-F. Separation of baicalin from Scutellaria Baicalensis Georgi with polyamide. J. Cent. South Univ. Technol. 2008, 15, 606-611. [CrossRef]

14. Wu, S.; Sun, A.; Liu, R. Separation and purification of baicalin and wogonoside from the Chinese medicinal plant Scutellaria baicalensis Georgi by high-speed counter-current chromatography. J. Chromatogr. A 2005, 1066, 243-247. [CrossRef]

15. Du, Z.; Wang, K.; Tao, Y.; Chen, L.; Qiu, F. Purification of baicalin and wogonoside from Scutellaria baicalensis extracts by macroporous resin adsorption chromatography. J. Chromatogr. B 2012, 908, 143-149. [CrossRef] [PubMed]

16. Ji, S.; Wang, Y.; Shao, X.; Zhu, C.; Lin, Y.; Gao, S.; Tang, D. Extraction and purification of triterpenoid saponins from licorice by ionic liquid based extraction combined with in situ alkaline aqueous biphasic systems. Sep. Purif. Technol. $2020,247,116953$. [CrossRef]

17. Glińska, K.; Bin Ismail, M.S.; Goma-Camps, J.; Valencia, P.; Stüber, F.; Giralt, J.; Fabregat, A.; Torrens, E.; Olkiewicz, M.; Bengoa, C. Recovery and characterisation of cellulose from industrial paper mill sludge using tetrakis and imidazolium based ionic liquids. Ind. Crop. Prod. 2019, 139, 111556. [CrossRef]

18. Martins, M.A.R.; Domańska, U.; Schröder, B.; Coutinho, J.A.P.; Pinho, S.P. Selection of Ionic Liquids to be Used as Separation Agents for Terpenes and Terpenoids. ACS Sustain. Chem. Eng. 2016, 4, 548-556. [CrossRef]

19. Vilková, M.; Płotka-Wasylka, J.; Andruch, V. The role of water in deep eutectic solvent-base extraction. J. Mol. Liq. 2020, 304, 112747. [CrossRef]

20. Owczarek, K.; Szczepanska, N.; Plotka-Wasylka, J.; Rutkowska, M.; Shyshchak, O.; Bratychak, M.; Namiesnik, J. Natural Deep Eutectic Solvents in Extraction Process. Chem. Chem. Technol. 2016, 10, 601-606. [CrossRef]

21. Rutkowska, M.; Płotka-Wasylka, J.; Majchrzak, T.; Wojnowski, W.; Mazur-Marzec, H.; Namieśnik, J. Recent trends in determination of neurotoxins in aquatic environmental samples. TrAC Trends Anal. Chem. 2019, 112, 112-122. [CrossRef]

22. Yao, K.; Zhao, C.; Wang, N.; Li, T.; Lu, W.; Wang, J. An aqueous synthesis of porous PtPd nanoparticles with reversed bimetallic structures for highly efficient hydrogen generation from ammonia borane hydrolysis. Nanoscale 2019, 12, 638-647. [CrossRef]

23. Dong, K.; Zhang, S.; Wang, D.; Yao, X. Hydrogen Bonds in Imidazolium Ionic Liquids. J. Phys. Chem. A 2006, 110, 9775-9782. [CrossRef]

24. Tsuzuki, S.; Tokuda, H.; Mikami, M. Theoretical analysis of the hydrogen bond of imidazolium C2-H with anions. Phys. Chem. Chem. Phys. 2007, 9, 4780-4784. [CrossRef] [PubMed]

25. Hunt, P.A.; Ashworth, C.R.; Matthews, R.P. Hydrogen bonding in ionic liquids. Chem. Soc. Rev. 2015, 44, 1257-1288. [CrossRef] 
26. Rasouli, S.; Davaran, S.; Rasouli, F.; Mahkam, M.; Salehi, R. Positively charged functionalized silica nanoparticles as nontoxic carriers for triggered anticancer drug release. Des. Monomers Polym. 2013, 17, 227-237. [CrossRef]

27. Dou, Q.; Liu, L.; Yang, B.; Lang, J.; Yan, X. Silica-grafted ionic liquids for revealing the respective charging behaviors of cations and anions in supercapacitors. Nat. Commun. 2017, 8, 1-9. [CrossRef]

28. Qiu, H.; Jiang, S.; Liu, X. N-Methylimidazolium anion-exchange stationary phase for high-performance liquid chroma-tography. J. Chromatogr. A 2006, 1103, 265-270. [CrossRef] [PubMed]

29. Wu, Y.; Li, Z.; Xia, C. Silica-Gel-Supported Dual Acidic Ionic Liquids as Efficient Catalysts for the Synthesis of Polyoxymethylene Dimethyl Ethers. Ind. Eng. Chem. Res. 2016, 55, 1859-1865. [CrossRef]

30. Niknam, K.; Piran, A. Silica-Grafted Ionic Liquids as Recyclable Catalysts for the Synthesis of 3,4-Dihydropyrano[c]chromenes and Pyra-no[2,3-c]pyrazoles. Green Sustain. Chem. 2013, 3, 1-8. [CrossRef]

31. Tarkhanova, I.; Zelikman, V.; Gantman, M. The complexes of copper with grafted ionic liquids in the environmentally important processes. Appl. Catal. A Gen. 2014, 470, 81-88. [CrossRef]

32. Wang, Q.; Baker, G.A.; Baker, S.N.; Colón, L.A. Surface confined ionic liquid as a stationary phase for HPLC. Analyst 2006, 131, 1000-1005. [CrossRef]

33. Sidhpuria, K.B.; Daniel-Da-Silva, A.L.; Trindade, T.; Coutinho, J.A.P. Supported ionic liquid silica nanoparticles (SILnPs) as an efficient and recyclable heterogeneous catalyst for the dehydration of fructose to 5-hydroxymethylfurfural. Green Chem. 2011, 13, 340-349. [CrossRef]

34. Yoon, J.-H.; Yoo, C.-I.; Ahn, Y.-S. N,N-dimethylformamide: Evidence of carcinogenicity from national representative cohort study in South Korea. Scand. J. Work. Environ. Health 2019, 45, 396-401. [CrossRef]

35. Filley, C.M.; Halliday, W.; Kleinschmidt-DeMasters, B.K. The Effects of Toluene on the Central Nervous System. J. Neuropathol. Exp. Neurol. 2004, 63, 1-12. [CrossRef] [PubMed]

36. El-Harbawi, M. Toxicity Measurement of Imidazolium Ionic Liquids Using Acute Toxicity Test. Procedia Chem. 2014, 9, 40-52. [CrossRef]

37. Quijano, G.; Couvert, A.; Amrane, A.; Darracq, G.; Couriol, C.; Cloirec, P.L.; Paquin, L.; Carrié, D. Toxicity and biodeg-radability of ionic liquids: New perspectives towards whole-cell biotechnological applications. Chem. Eng. J. 2011, 174, 27-32. [CrossRef]

38. Nagao, D.; Osuzu, H.; Yamada, A.; Mine, E.; Kobayashi, Y.; Konno, M. Particle formation in the hydrolysis of tetraethyl orthosilicate in pH buffer solution. J. Colloid Interface Sci. 2004, 279, 143-149. [CrossRef] [PubMed]

39. Nuryono, N.; Miswanda, D.; Sakti, S.C.W.; Rusdiarso, B.; Krisbiantoro, P.A.; Utami, N.; Otomo, R.; Kamiya, Y. Chi-tosanfunctionalized natural magnetic particle@silica modified with (3-chloropropyl)trimethoxysilane as a highly stable magnetic adsorbent for gold(III) ion. Mater. Chem. Phys. 2020, 255, 123507. [CrossRef]

40. Wang, N.; Zhou, X.; Cui, B. Synthesis of a polymeric imidazolium-embedded octadecyl ionic liquid-grafted silica sorbent for extraction of flavonoids. J. Chromatogr. A 2019, 1606, 460376. [CrossRef]

41. Yin, K.; Zhang, Z.; Li, X.; Yang, L.; Tachibana, K.; Hirano, S.-I. Polymer electrolytes based on dicationic polymeric ionic liquids: Application in lithium metal batteries. J. Mater. Chem. A 2014, 3, 170-178. [CrossRef]

42. Zheng, Y.-F.; Wei, J.-H.; Qi, L.-W.; Cheng, J.-M.; Peng, G.-P. A green and efficient protocol for large-scale production of glycyrrhizic acid from licorice roots by combination of polyamide and macroporous resin adsorbent chromatography. J. Sep. Sci. 2013, 36, 809-816. [CrossRef]

43. Far, H.S.; Hasanzadeh, M.; Nashtaei, M.S.; Rabbani, M.; Haji, A.; Moghadam, B.H. PPI-Dendrimer-functionalized mag-netic metal-organic framework $\left(\mathrm{Fe}_{3} \mathrm{O}_{4} @ \mathrm{MOF} @ \mathrm{PPI}\right)$ with high adsorption capacity for sustainable wastewater treatment. ACS Appl. Mater. Inter. 2020, 12, 25294-25303. [CrossRef]

44. Irshad, M.A.; Shakoor, M.B.; Ali, S.; Nawaz, R.; Rizwan, M. Synthesis and Application of Titanium Dioxide Nanoparticles for Removal of Cadmium from Wastewater: Kinetic and Equilibrium Study. Water Air Soil Pollut. 2019, 230, 278. [CrossRef]

45. Oyelude, E.O.; Awudza, J.A.M.; Twumasi, S.K. Equilibrium, Kinetic and Thermodynamic Study of Removal of Eosin Yellow from Aqueous Solution Using Teak Leaf Litter Powder. Sci. Rep. 2017, 7, 12198. [CrossRef]

46. Yoshizuka, K.; Ohta, H.; Inoue, K.; Kitazaki, H.; Ishimaru, M. Selective separation of flavonoids with a polyvinyl alcohol membrane. J. Membr. Sci. 1996, 118, 41-48. [CrossRef]

47. Kaur, R.; Kaur, A.; Umar, A.; Anderson, W.A.; Kansal, S.K. Metal organic framework (MOF) porous octahedral nano-crystals of Cu-BTC: Synthesis, properties and enhanced adsorption properties. Mater. Res. Bull. 2019, 109, 124-133. [CrossRef] 